\title{
Effect of recombinant vertebrate growth hormones on growth of adult abalone, Haliotis kamtschatkana
}

\author{
Barbara E. Taylor ${ }^{\text {a, }}$, Deborah A. Donovan ${ }^{a}$, Ewen McLean ${ }^{\mathrm{b}, 1}$, \\ Edward M. Donaldson ${ }^{\mathrm{b}}$, Thomas H. Carefoot ${ }^{\mathrm{a}}$ \\ a Department of Zoology, University of British Columbia, 6270 University Boulevard, Vancouver, BC V6T \\ 1Z4, Canada \\ ${ }^{b}$ Department of Fisheries and Oceans, West Vancouver Laboratory, 4160 Marine Drive, West Vancouver, BC \\ VTV IN6, Canada
}

\begin{abstract}
Enhancement of cultivar growth through hormone treatment is of interest in aquaculture research owing to its potential for increasing production. In this study, injection of exogenous growth hormones was investigated as a means of enhancing growth in adult abalone, Haliotis kamtschatkana. Fifty individually caged abalone were held in a common aquarium tank with a constant flow of fresh ambient seawater and fed ad libitum on kelp (Nereocystis leutkeana). The abalone were divided into five groups of ten animals each. Every group had a similar mean weight $(78 \mathrm{~g})$ and length $(7 \mathrm{~cm})$. Four groups received weekly intramuscular injections $\left(5 \mu \mathrm{g} \mathrm{g}^{-1}\right.$ body weight) of either (1) recombinant bovine growth hormone, (2) recombinant porcine growth hormone, (3) somatostatin, or (4) bovine serum albumin. The fifth group served as an uninjected control. The abalone were weighed biweekly throughout the 10 week experiment. Water content and gonad index were assessed for each group at the end of the experimental period. There were no significant differences in weight gain, water content, or gonad index among the five groups.
\end{abstract}

Keywords: Abalunc; Growth; Growth hormones; Huliotis kemrisctutkuru

\section{Introduction}

Techniques for manipulating growth in aquacultured organisms have received intensive study over the last decade. In part, this has occurred because of the advent of recombinant (r) DNA technologies, which provide the means for producing large

\footnotetext{
* Corresponding author.

${ }^{1}$ Present address: University of Aalborg, Faculty of Technology and Science, Aquaculture Biotechnology Laboratory, Sohngaardsholmsvej 57, Dk-9000, Aalborg, Denmark.
} 
quantities of biologically active proteins. In teleosts, specifically, a voluminous literature exists to demonstrate the growth-accelerating effects of recombinant growth hormones (rGHs) (reviewed by McLean and Donaldson, 1993). In contrast, comparatively few studies have examined the endocrine basis for growth in molluscs, even though recent findings have indicated an endocrine foundation for growth regulation.

That molluscs possess GH-like molecules has been known since Lubet (1971) worked with the gastropod Crepidula fornicata. Later, Geraerts (1976) characterized a growth hormone produced by neurosecretory cells in the cerebral ganglia of Lymnaea stagnalis. This hormone was subsequently shown to stimulate shell growth (Dogterom et al., 1979; Dogterom and Jentjens, 1980) and to influence certain metabolic pathways (Dogterom, 1980; Dogterom and Robles, 1980). The molluscan hormone, which is an insulin-like peptide, is often referred to as molluscan insulin-like peptide (MIP). It has been isolated and sequenced (Smit et al., 1988), and the series of genes coding for MIP in L. stagnalis has been identified (Smit et al., 1992). Two GH-like substances have been purified from Haliotis discus hannai (Moriyama et al., 1989). There is also evidence to suggest that gastropods possess a somatostatin-like growth-promoting molecule (Grimm-Jørgensen, 1983a; Grimm-Jørgensen, 1983b; Marchand et al., 1989). Thus, growth-regulating substances in gastropods are being actively researched. However, these molecules are not commercially available.

That exogenous hormones can influence molluscan growth was shown by Morse (1981), who observed enhanced growth of postlarval $H$. rufescens after treatment with mammalian insulin and growth hormone. More recently, Kawauchi and Moriyama (1991) reported that recombinant salmonid GH stimulated growth in $H$. discus hannai, while Paynter and Chen (1991) showed that a recombinant trout GH stimulated growth of larval eastern oyster, Crassostrea virginica. To date, such studies on molluscs have centered upon juvenile stages. In the present study, we examined the effects of rGH treatment on adult abalone, using both recombinant bovine and porcine GHs. Since a molluscan GH similar to somatostatin has been reported, one group of animals was treated with this peptide.

\section{Methods and materials}

Northern abalone, H. kamtschatkana, were collected in Barkley Sound on the west coast of Vancouver Island, British Columbia, and transported to the Department of Fisheries and Oceans Laboratory in West Vancouver. Fifty of these abalone were individually caged and held in a common aquarium tank with a constant flow of fresh seawater $\left(12^{\circ} \mathrm{C}\right)$. During a 2 -week acclimation period and throughout the experiment the animals were fed kelp, Nereocystis leutkeana. The abalone were divided into five groups of ten animals each. Every group had a similar mean weight $(78 \mathrm{~g})$ and length (7 $\mathrm{cm})$. Four groups received weekly intramuscular injections of either (1) recombinant bovine growth hormone (rbGH), (2) recombinant porcine growth hormone (rpGH), (3) somatostatin (SST), or (4) bovine serum albumin (bsa). Bovine serum albumin was selected to provide an equivalent dose of protein, but one not potentially active in stimulating growth. The fifth group of abalone was untreated, but was handled in the 
same way as the experimental groups. Since both previous studies on vertebrate hormone therapy in abalone (Morse, 1981; Kawauchi and Moriyama, 1991) employed immersion rather than injection, no guidelines for the selection of an appropriate injection dosage were available. Accordingly, we selected our dosage of $5 \mu \mathrm{g} \mathrm{g}^{-1}$ body weight based on previous work with salmon (Down et al., 1988; McLean and Donaldson, 1993). We administered hormones by injection rather than immersion because relying on diffusion with larger animals would be inappropriate in commercial settings. Injections were made intramuscularly at $1 \mathrm{~cm}$ depth in the center of the foot sole, and consisted of $100 \mu \mathrm{l}$ total volume of hormone plus saline. Animals were not anaesthetized prior to injection.

Live wet weights of the abalone were obtained biweekly throughout the 10 week experiment. Water content and gonad index were assessed for five animals from each treatment group at the end of the experimental period. To determine water content, abalone were dried to constant weight at $60^{\circ} \mathrm{C}$, while gonad index was measured as percentage ratio of dry gonad weight to total dry soft tissue weight. All data were analyzed using repeated measures ANOVA coupled with Tukey's multiple comparison tests.

\section{Results}

Fig. 1 shows mean live weights of abalone undergoing the various hormone therapies. Only abalone which survived the 10 week duration of the study have been included in

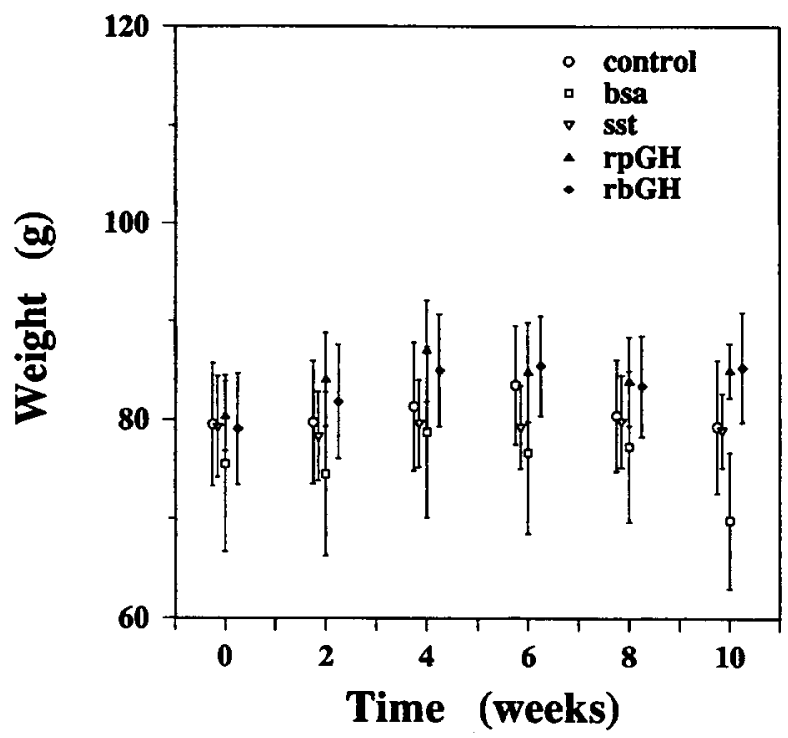

Fig. 1. Live weights of abalone treated with biweekly injections of bovine serum albumin (bsa), somatostatin (sst), recombinant porcine growth hormone (rpGH), recombinant bovine growth hormone (rbGH), and an untreated control group. Data are means \pm s.e. for sample sizes ranging from five to eight. 
the graph and statistical analyses. Mortalities among the treatment groups were higher than expected, with four and five animals dying in the rbGH and $\mathrm{rpGH}$ treatments, respectively, and two in each of the other treatments. The data suggest that handling and needle-injection stress may have caused some of these mortalities, perhaps exacerbated by effects of the rGH hormones themselves.

While there appeared to be some differences in final weight among the various treatments, these were not significant $\left(F_{4,32}=0.219, P=0.93\right.$; Fig. 1). There was, however, a significant $\left(F_{4,32}=5.876, P<0.001\right)$ time effect, with animals gaining weight over the first 5-7 weeks of the study (overall mean weight increased from 78.7 live $\mathrm{g} \pm 3.1$ s.e. to 82.3 live $\mathrm{g} \pm 3.1$ s.e.). However, over the remainder of the study the abalone lost this weight, and by 10 weeks were not significantly different from their initial weight (Tukey's test; $P>0.05$ ).

Results of the ANOVA comparing body water content between treatments with weight factored out indicate that no treatment had a significant influence on tissue water content $\left(F_{4,20}=3.704, P=0.06\right)$. Overall water content was $79.2 \pm 0.5$ s.e. of live soft tissue weight.

Results of the ANOVA gonad indices between treatments with weight factored out indicate that no treatment significantly influenced gonad index $\left(F_{4,20}=0.726, P=0.60\right)$. There was, however, a significant difference in gonad indices of males versus females $\left(F_{1,20}=8.190, P=0.02\right)$. Overall, gonad index for females was $24.4 \% \pm 1.1$ s.e. and for males $19.5 \% \pm 0.9$ s.e. of live soft tissue weight.

\section{Discussion}

Unlike previous studies which report enhancement of growth by using vertebrate hormones on juvenile abalone (Morse, 1981; Kawauchi and Moriyama, 1991), our results showed no effect. Whether adult abalone truly do not respond to rpGH, rbGH, or vertebrate SST, or whether the dosage or mode of application was wrong, cannot be discerned from our data. However, it is possible that growth in adult abalone may be so controlled by the reproductive cycle as not to be influenced by exogenous hormones. Such a competitive inhibition between reproductive and somatic growth in abalone is suggested by exponentially decreasing growth rates with age (Leighton and Boolootian, 1963; Quayle, 1971; Paul et al., 1976). Decreased growth rate appears not just to be the result of general decline in metabolism among older animals, but rather to be at least partly due to the competitive demand of the gonad for energy. In support of this, a number of authors have reported decreased growth rates for abalone specifically during periods of gonad production (Shepherd and Hearn, 1983; Keesing and Wells, 1989), and negligible growth during most of the year except for a growth spurt after spawning (Cox, 1962; Foster, 1967; Poore, 1972; Sainsbury, 1982; Keesing and Wells, 1989). The present study took place over 10 weeks from April to July, which corresponds to the time of gametogenesis and negligible somatic growth in $H$. kamtschatkana (Paul et al., 1976). This time was chosen intentionally in order to test the effectiveness of hormone therapy when the animals were least predisposed to somatic growth (thus presenting the greatest challenge to our protocol). In retrospect this may have been unwise, since 
commitment to reproductive growth over the time-course of the experiment may have been irreversible, thus possibly explaining the lack of response in somatic growth. If it is the case that adult abalone are irreversibly committed to reproductive growth at the expense of somatic growth, it is also evident from the present study that reproductive growth is not affected by exogenous vertebrate growth hormones. Regardless of treatment, females had an average gonad index of $24.4 \%$ and males $19.5 \%$, values comparable to another North American abalone, H. cracherodii (20\% of its soft body parts; Webber, 1970).

Another possible explanation for lack of response in somatic growth to hormone treatment in our study is suggested by the observation of Toullec et al. (1988) that the lacunar nature of molluscan circulatory systems is unfavorable for in vivo injection of hormonal substances, owing to the sluggish and inefficient movement of hemolymph. Even so (and assuming that growth-enhancement hormones can ultimately be identified for abalone), it is evident that an alternative, less time-consuming method of delivery should be adopted. Immersion of adult abalone does not seem logistically possible in a culture circumstance; however, incorporation of suitable growth-promoting substances into the animals' feed may have potential. Additionally, transgenetic fish have been developed with remarkable growth rates (Cavari et al., 1993; Devlin et al., 1994), and it is possible that similar methodologies could be applied to abalone.

\section{Acknowledgements}

We would like to thank the staff at the West Vancouver Laboratory of DFO of Canada, in particular Andy Lamb, for facilitating our research, and Dr. Andy Spencer, Director, Bamfield Marine Station, and his staff for allowing collection of the animals. Growth hormones were a kind gift from Dr. L.M. Souza, Amgen Inc., Thousand Oaks, CA, USA.

\section{References}

Cavari, B., Funkenstein, B., Chen, T.T., Gonzalez-Villasenor, L.I. and Schart, M., 1993. Effect of growth hormone on the growth rate of the gilthead seabreem (Sparus aurata), and use of different constructs for the production of transgenic fish. Aquaculture, 111: 189-197.

Cox, K.W., 1962. Califomia abalones, family Haliotidae. Fish. Bull. Cal., vol. 118, 130 pp.

Devlin, R.H., Yesaki, T.Y., Biagi, C.A. and Donaldson, E.M., 1994. Extraordinary salmon growth. Nature, 371: 209-210.

Dogterom, A.A., 1980. The effect of the growth hormone of the freshwater snail Lymnaea stagnalis on biochemical composition and nitrogenous wastes. Comp. Biochem. Physiol., 65B: 163-167.

Dogterom, A.A. and Jentjens, T., 1980. The effect of the growth hormone of the pond snail Lymnaea stagnalis on periostracum formation. Comp. Biochem. Physiol., 66A: 687-690.

Dogterom, A.A. and Robles, B.R., 1980. Stimulation of omithine decarboxylase activity in Lymnaea stagnalis after a single injection with molluscan growth hormone. Gen. Comp. Endocrinol., 40: 238-240.

Dogterom, A.A., Van Loenhout, H. and Van Der Schors, R.C., 1979. The effect of growth hormone of Lymnaea stagnalis on shell calcification. Gen. Comp. Endocrinol., 39: 63-68.

Down, N.E., Donaldson, E.M., Dye, H.M., Langley, K. and Souza, L.M., 1988. Recombinant bovine 
somatotropin more than doubles the growth rate of coho salmon (Oncorhynchus kisutch) acclimated to seawater and ambient winter conditions. Aquaculture, 68: 141-155.

Foster, G.R., 1967. The growth of Haliotis tuberculata: Results of tagging experiments in Guemsey $1963-65$. J. Mar. Biol. Assoc. UK, 47: 287-300.

Geraerts, W.P.M., 1976. Control of growth by the neurosecretory hormone of the light green cells in the freshwater snail Lymnuea stugnulis. Gen. Comp. Endocrinol., 29: 61-71.

Grimm-Jørgensen, Y., 1983a. Immunoreactive somatostatin in two pulmonate gastropods. Gen. Comp. Endocrinol., 49: 108-114.

Grimm-Jørgensen, Y., 1983b. Possible physiological roles of thyrotropin releasing hormone and a somatostatin-like peptide in gastropods. In: J. Lever and H.T. Boer (Editors), Proc. Int. Minisymposium on Molluscan Endocrinology. Amsterdam, 1982, pp. 21-28.

Kawauchi, H. and Moriyama, S., 1991. Characterization of abalone growth hormone-like protein. In: Short Communications of the 1991 International Marine Biotechnology Conference. Vol. Il. Developments in Industrial Microbiology. Extended Abstract Ser., Wm. C. Brown, pp. 535-541.

Keesing, J.K. and Wells, F.E., 1989. Growth of abalone Haliotis roei Gray. Aust. J. Mar. Freshwater Res., 40: 199-204.

Leighton, D. and Boolootian, R.A., 1963. Diet and growth in the black abalone Haliotis cracherodii. Ecology, 44: 227-238.

Lubet, P., 1971. Influence des ganglions cérébroïdes sur la croissance de Crepidula fornicata Phil. (Mollusque mesogastéropcile). C. R. Acad. Sci., 273: 2309-2311.

Marchand, C.R., Assaka, L. and Strosser, M.T., 1989. Variations of somatostatin-like immunoreactivity in the circumoesophageal ganglia, the hepatopancreas, the mantle edge, and the hemolymph of shell-repairing snails (Helix aspersa). Gen. Comp. Endocrinol., 73: 59-68.

Mclean, E. and Donaldson, E.M., 1993. The role of growth hormone in the growth of poikilotherms. In: M.P. Schreibman, C.G. Scanes and P.K.T. Pang (Editors), The Endocrinology of Growth, Development and Metabolism in Vertebrates. Academic Press, San Diego, CA, pp. 43-71.

Moriyama, S., Atsuta, S., Kobayashi, M. and Kawauchi, H., 1989. Growth hormone-like substance of abalone Haliotis discus hannai. In: A. Epple, C.G. Scanes and M.H. Stetson (Editors), XIth Int. Symp. Comparative Endocrinology. Malaga, 14-20 May 1989.

Morse, D.E., 1981. Biochemical and Genetic Control of Critical Physiological Processes in Molluscan Life-Cycles: Basic Mechanisms, Water-Quality Requirements and Sensitivities to Pollutants. University of Califomia Press, La Jolla, CA.

Paul, A.J., Paul, J.M., Hood, D.W. and Nevé, R.A., 1976. Observations on food preferences, daily ration requirements and growth of Haliotis kamtschatkana Jonas in captivity. Veliger, 19: 303-309.

Paynter, K.T. and Chen, T.T., 1991. Biological activity of biosynthetic rainbow trout growth hormone in the eastern oyster, Crassostrea virginica. Biol. Bull., 181: 459-462.

Poore, G.C., 1972. Ecology of New Zealand abalones, Haliotis species (Mollusca: Gastropoda). 3. Growth. N.Z. J. Mar. Freshwater Res., 6: 534-559.

Quayle, D.B., 1971. Growth, morphometry and breeding in the British Columbia abalone (Haliotis kamtschatkana Jonas). Fish. Res. Board Can., Tech. Rep. No. 279, 16 pp.

Sainsbury, K.J., 1982. Population dynamics and fishery management of the paua, Haliotis iris. I. Population structure, growth, reproduction, and mortality. N.Z. J. Mar. Freshwater Res., 16: 147-161.

Shepherd, S.A. and Hearn, W.S., 1983. Studies of southern Australian abalone (genus Haliotis). IV. Growth of $H$. laevigata and $H$. ruber. Aust. J. Mar. Freshwater Res., 34: 461-475.

Smit, A.B., Vreugdenhil, E., Ebberink, R.M.N., Geraerts, W.P.M., Klootwijk, J. and Joosse, J., 1988. Growth-controlling molluscan neurons produce the precursor of an insulin-related peptide. Nature, 331: 535-538.

Smit, A.B., Thijsen, S.H., Geraerts, W.P.M., Meester, I., Van Heerikhuizen, H. and Joosse, J., 1992. Characterization of a cDNA clone encoding molluscan insulin-related peptide $\mathrm{V}$ of Lymnaea stagnalis. Mol. Brain Res., 14: 7-12.

Toullec, F.L., Van Waormhoudt, A. and Mathieu, M., 1988. Non-species-specific growth factor from cerebral ganglia of Mytilus edulis. J. Exp. Mar. Biol. Ecol., 119: 111-117.

Webber, H.H., 1970. Changes in metabolite composition during the reproductive cycle of the abalone Haliotis cracherodii (Gastropoda: Prosobranchiata). Physiol. Zool., 43: 213-231. 